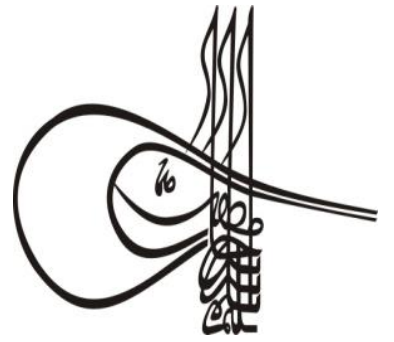

\section{Economics, Finance, Politics}

Volume 14 Issue 2, 2019, p. 335-355

DOI: 10.29228/TurkishStudies.22921

ISSN: 2667-5625

Skopje/MACEDONIA-Ankara/TURKEY

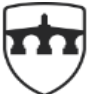

INTERNATIONAL BALKAN UNIVERSITY

EXCELLENCE FOR THE FUTURE IBU.EDU.MK

ResearchArticle / Araştırma Makalesi

ArticleInfo/MakaleBilgisi

\Accepted/Kabul: 10.06 .2019

Received/Geliş: 11.03.2019

1 (29.04.2019)- Referee 2 (30.04.2019)

This article was checked by iThenticate.

\title{
YATIRIM İZLEME VE KOORDİNASYON BAŞKANLIĞI ÜZERİNE BİR INCELEME*
}

\author{
Mustafa KALENDER ${ }^{* *}$ - Çiğdem AKMAN"**
}

\begin{abstract}
Öz
2012 y1lında çıkarılan 6360 sayılı On Dört İlde Büyükşehir Belediyesi ve Yirmi Yedi İlçe Kurulması ile Bazı Kanun ve Kanun Hükmünde Kararnamelerde Değişiklik Yapılmasına Dair Kanun ile yerel yönetim sisteminde köklü değişiklikler meydana gelmiştir. Bu çerçevede büyükşehir belediyelerinin sayısı artmış, büyükşehir belediye sınırları il mülki sınırları haline getirilerek genişletilmiş, il özel idareleri kapatılmış ve köyler mahalleye dönüştürülmüştür. 6360 Sayılı Kanun kapsamında kapatılan il özel idarelerinin görev ve sorumlulukları büyükşehir belediyeleri ve yine bu kanun kapsamında kurulan Yatırım İzleme ve Koordinasyon Başkanlığı'na devredilmiştir. Bu bağlamda çalışmanın amac1, bir yerel yönetim birimi olan il özel idarelerinin kapatılarak bazı görev ve sorumluluklarının merkezi bir teşkilat olan Yatırım İzleme ve Koordinasyon Başkanlığı'na devredilmesinin, yerel yönetim sistemine etkilerinin araştırılmasıdır. Ege bölgesinde yer alan tüm büyükşehirlerdeki Yatırım İzleme ve Koordinasyon Başkanlıkları örneklem olarak belirlenmiş ve Ege bölgesindeki Yatırım İzleme ve Koordinasyon Başkanları ve yöneticileri ile nitel bir araştırma tekniği olan mülakat yapılmıștır. Mülakat esnasında Yatırım İzleme ve Koordinasyon Başkanlığı hem teşkilat yapısı, görev, yetki ve sorumlulukları, mali yapısı ve denetimi ile ilgili hususlar hakkında bilgi alınmış hem de bu kurum hakkında merak edilen sorulara cevap aranmıştır. Çalışma kapsamında, il özel idaresinin Yatırım İzleme ve Koordinasyon Başkanlığı'na devredilen görev ve sorumluluklarında
\end{abstract}

\footnotetext{
* Bu çalışma “İl Özel İdaresi Sisteminden Yatırım İzleme ve Koordinasyon Başkanlığına Geçiş: Ege Bölgesinde Nitel Bir Analiz" isimli tezden üretilmiştir.

Bilim Uzman1,E-posta: mkalender11@gmail.com

Dr. Öğr. Üyesi, Süleyman Demirel Üniversitesi, E-posta: cigdemargun@ hotmail.com
} 
çeşitli aksaklıklar meydana geldiği ve yeni bir yasal düzenlemeye ihtiyaç duyulduğu tespit edilmiştir.

Anahtar Kelimeler: İl Özel İdaresi, Yatırım İzleme ve Koordinasyon Başkanlığı, 6360 sayılı Kanun.

\title{
AN INVESTIGATION ON THE INVESTMENT, MONITORING AND COORDINATION DIRECTORATE
}

\begin{abstract}
In 2012, the Law No. 6360 under the title of "The Establishment of Fourteen Metropolitan Municipalities and Twenty-seven Districts and Amendments on Certain Lawand Decree Laws" has introduced fundamental changes to the local government system. Within this framework, the number of metropolitan municipalities has increased, the jurisdictionareas of metropolitan municipalipalities were enlarged from town centers to the provincial bound aries, authorities of the Special Provincial Administrations were undertaken by both the metropolitan municipalities and the Investment, Monitoring and Coordination Directorate. In this regard, the objective of the present study is to investigate the impact of termination of the Special Provincial Administrations and transfer of their authorities and responsibilities to the Investment, Monitoring and Coordination Directorate, a central government body, on local government system. The sampling group of the study was comprised of the all Investment, Monitoring and Coordination Directorates located in metropolitan cities across the Aegean region. An interview study, a qualitative research method, was conducted with the Heads and Executives of the Investment, Monitoring and Coordination Directorates included in the study. During the interviews, the information on the organizational structure, duties, authorities and responsibilities, financial structure and supervision of the Investment, Monitoring and Coordination Directorate were collected as well as institutialization of afore said bodies. Within the scope of the study, it was determined that various disruptions have occurred in the duties and responsibilities of the Special Provincial Administrations transferred to the Investment, Monitoring and Coordination Directorates, and that a new legal regulation is required.
\end{abstract}

\section{STRUCTURED ABSTRACT}

In Turkey, decisions concerning local administrations have been taken and put in effect in a brief period of time. Although there has been almost no any amendment made with the Special Provincial Administrations (SPA) established by the 1864 City Regulation until 1987 ,the law with $5302^{\text {nd }}$ Serial number and the Law with $6360^{\text {th }}$ Serial number have introduced significant changes in 2005 and 2012, respectively. Whereas amendments in 2005 were relatively minor, the ones introduced in 2012 were fundamental in every aspect. Whereas the Law with 6360 serial number increased number of metropolitan municipalities to 30 , the SPAs in metropolitan cities were replaced with Investment, MonitoringandCoordinationDirectorate (IMCD).

Turkish Studies - Economics, Finance, Politics

Volume 14 Issue 2, 2019 
The objective of the present study is to investigate into the effect of transfer of duties and authorities of SPAs to IMCDs on the local administration system. Furthermore, it aims to make suggestions on potential future amendments on the existing legislation on IMCDs. In this study, IMCD's organizational structure, task, authority and responsibilities, financial structure and auditing were investigated as well as the point of views of administrators and chairmen of IMCD toward this new organization. The universe of the study is comprised of all metropolitan cities in Turkey whereas our sampling is all metropolitan cities located in Aegean Territory. In line with the sampling of the study, interview method, a qualitative research technic, was applied to all IMCDs located in the Aegean Territory including Aydin, Muğla, Denizli, Manisa and İzmir Cities. From four administrators in each of 5 cities were requested for interview; but totally 19 administrators were interviewed. Of these administrators, IMCD President, Director of Administrative and Financial Affairs, Director of Strategy and Coordination, and Director of Investment Monitoring. Aforesaid interviews were conducted in August 2017 and took average 35 to 65 minutes. During the interviews, questions concerning operation of IMCD, such as organizational structure, task, authority and responsibilities, financial structure, auditing and some others were asked to the relevant person. Within the framework of these questions, suggestions of administrators for improving efficiency of IMCD were seen to be related with a non-politic structure funded with share from taxes and to create its own income budget necessary for its investments, and employ its own personnel. This described structure recalls SPAs without a General City Board.

Abolishment of SPA, a local administration, across metropolitan cities and foundation of IMCDs, a central organization, has brought various arguments. The most prominent one of these arguments was centralization. The primary criticism toward centralization is replacement of elected members of City General Board of the Executive body of SPA with the governor who is assigned to executive board of IMCDs authorized with investment decisions and undertook the projects such as Rural Infrastructure Support Project (KIRDES). The major rationale of the ones against the claims of centralization was the transfer of some authorities and responsibilities of SPAs relevant with investments to the metropolitan municipalities. Moreover, extensive amendments made on SPA Laws in a short notice caused criticisms that amendments on laws were made without a certain plan. Finally, provision of legal entity to IMCDs after their foundation has intensified aforesaid criticisms.

As a result of the interviews made within the interviews, it was determined that the biggest problem with the IMCDs in Aegean Region was task/personnel number. Another circumstance that came forward during interviews was the problems that arise subject to different political party background of metropolitan municipality administrations and central government. Allocation of assets remained from SPAs and disagreements on distribution of authority and responsibilities were the foundation of these problems. While metropolitan municipalities were of the opinion that they were the sole party authorized with investment, central government could intervene into investment and public services decisions through IMCDs. This situation has turned into authority

Turkish Studies - Economics, Finance, Politics

Volume 14 Issue 2, 2019 
conflict in some cities. In this regard, it was three major problems determined with IMCDs:

- Due to obscurity in description of tasks, confusion in authority and consequent stagnation could take place in operations;

- Due to failure to describe income items, lack of capacity to use investment authority and consequently inefficient performance on tasks;

- Due to insufficient number of personnel, overwork of current personnel.

Along the interviews conducted with administrators, it was emphasized that the issue concerning foundation of IMCDs across IMCD 51 cities in which SPAs were still in operation was asked to IMCD Administration by the Ministry of Internal Affairs. Especially before the 2019 mayoral elections, such amendment was expected by interviewed administrators but it did not happen.

In general consideration of study findings, numbers of administrators who showed positive response to foundation of IMCDs and the ones who are with positive attitude toward foundation of IMCDs in all cities were close to each other. The numbers of administrators who stated that foundation of IMCDs did not affected local democracy and who were of the opinion that it did not have negative impact on principle of locality were found same. Moreover, the number of administrators who perceived Foundation of IMCD negatively and the ones argued that IMCDs were not capable of exhibiting the same performance with SPAs were same.

It was also observed that IMCD administrators from 5 Aegean Cities exhibited difference in some issues as below;

- While expenditure authority was given to the city governor in some IMCDs, department directors were authorized in some others.

- While some IMCDs are supported by the personnel from other public organizations through interim assignment when necessary, this was accomplished for some others even though there was authorization to do so.

- While some IMCDs have not been audited since their foundation, some others experienced two auditing.

- While some IMCDs were of the opinion that metropolitan municipalities were not authorized to audit their investment and services, some on the contrary.

In line with the opinions exposed by interviewed administrators, following changes may be introduced with IMCDs:

- IMCDs are required to be authorized to employ own personnel. But, this authority should not cause nepotism.

- In general, description of the organization, its tasks and authorities are required to be reviewed and clarified.

- IMCDs need to employ a vice governor with engineering background.

Turkish Studies - Economics, Finance, Politics

Volume 14 Issue 2, 2019 
- Interim personnel assignment should be ceased as a way of supplying personnel.

- Necessary corrective measures should be taken with the IMCD city directorates with physical environment deficiency.

- If IMCDs would be able to use investment authority, their income items are required to be clarified. Furthermore, these investments are to be determined in line with current needs of local areas and governors should be relieved from political pressures.

Conclusively, it was determined that foundation of IMCDs was necessary since there is no certain organization to undertake some tasks and responsibilities of terminated SPAs. However, there has been certain dissatisfaction with IMCDs founded within the framework of the Law with $6360^{\text {th }}$ Serial number even by its own personnel. Accordingly, certain deficiencies with description of institutional tasks, authority and responsibilities, structure, personnel regime and financial matters are required to be reviewed for solution.

Keywords: Special Provincial Administration, Investment, Monitoring and Coordination Directorate, Law No. 6360.

\section{Giriş}

Osmanlı Devleti'nden Türkiye Cumhuriyeti'ne miras olarak kalan il özel idareleri uzun y1llar aynı özellikleriyle işlevini sürdürmüştür. 1864 Vilayetler Nizamnamesinden 1987 yılına kadar il özel idaresi ile ilgili olarak neredeyse hiç bir değişiklik yapılmamıştır. $\mathrm{Bu}$ tarihten sonra ise çeşitli değişikliklere uğramıştır. 1987 yılında çıkarılan 3360 sayılı Kanun ve 2005 yılında çıkarılan 5302 sayılı Kanunla il özel idarelerinin yapısında önemli değişikliklere gidilmiş̧tir. İlk olarak 3360 sayılı Kanun ile İl Özel İdaresi Kanunu adını almış ve yapısı ve işleyişiyle ilgili birçok önemli düzenleme yapılmıştır. 5302 sayılı Kanun ile de il genel meclisinin vali karşısında konumu güçlendirilmiş ve görev ve sorumlulukları yeniden düzenlenmiştir.

Son olarak il özel idaresi ile ilgili, 2012 yılında çıkarılan 6360 sayılı Kanun ile köklü değişiklikler yapılmıştır. 6360 sayılı Kanun ile öncelikle büyükşsehir olan illerin sayısı 30'a çıkarılmış ardından da büyükşehirlerdeki il özel idareleri kapatılmıştır. Kapatılan il özel idarelerinin bulunduğu büyükşehirlere ise yine aynı kanunla Yatırım İzleme ve Koordinasyon Başkanlıkları kurulmuştur.

Bir yerel yönetim kuruluşu olan il özel idaresinin büyükşehir illerinde kaldırılması ve kaldırılan illere merkezi bir teşkilat olan Yatırım İzleme ve Koordinasyon Başkanlıklarının (YIKOB) kurulması çeşitli tartışmaları da beraberinde getirmiştir. Bu tartışmalardan en önemlisi merkezileşme tartışmalarıdır. Merkezileşme adımı olarak görenlerin temel gerekçesi il özel idaresinin karar organının seçilmiş yerel siyasetçilerden oluşan il genel meclisi iken, yatırım yetkisi bulunan ve Kırsal Altyapı Destekleme Projesi (KIRDES) gibi projelerin sorumluluğunu üstlenen YİKOB'larda karar organının atanmış bir bürokrat olan valinin olmasıdır. Merkezileşme adımı olarak görmeyenlerin ise temel gerekçesi, kapatılan il özel idaresinin yatırımla ilgili bazı yetki ve sorumluluklarının büyükşehir belediyelerine devredilmiş ve hali hazırda büyükşehir belediye meclisinin il genel meclisi gibi faaliyetlerini sürdürüyor olmasıdır.

6360 sayılı Kanun ile yapılan bazı değişiklikler ve il özel idaresinin kaldırılmasıyla ortaya çıkan bazı boşluklar, hem akademik çevrede hem de yerel yöneticilerde yerel yönetimlerle alakalı yeni bir yasal düzenleme beklentisini doğurmuştur. Özellikle 2017 yılında yapılan referandumla birlikte bir sistem değişikliğinin yaşanmış olması bu beklentiyi doğuran en önemli etmendir. Ayrıca 64 . Hükümetin açıkladığı 10 maddelik acil eylem planı arasında da yerel yönetimlerle alakalı bir 
düzenleme yapılacağı belirtilmişti. Ancak hükümet sistemi değişikliği nedeniyle ertelenen bu değişimin ne zaman gerçekleşeceği belli değildir. Bazı hususların yeniden gözden geçirilmesi oldukça önemli görülmektedir. Bu bağlamda çalışmada, il özel idarelerinin YİKOB'a devredilen görev ve sorumluluklarının yerel yönetimlerde nasıl bir etki doğurduğunu araştırmanın yanı sıra ileride YİKOB'lar ile ilgili yapılabilecek olan yasal düzenlemeler için önerilerde bulunmak amaçlanmaktadır. Çalışmada öncelikle YİKOB'lar hakkında bilgi verilmiş, hemen ardından Ege Bölgesinde yer alan YİKOB'lar üzerinden bir analiz yapılarak bazı değerlendirmelerde ve önerilerde bulunulmuştur.

\section{Yatırım İzleme Ve Koordinasyon Başkanlığı}

İl özel idarelerinin yasal temeli 1839 tarihli Tanzimat Fermanı ile atılmış, 1864 Vilayet Nizamnamesi ile de eyalet sisteminden vilayet sistemine geçilmiş̧ir (Parlak, 2015: 71). Osmanlı taşra teşkilâtında ortaya çıkan köklü bir yapılanma ihtiyacını karşılamak ve oluşturulmak istenen yapının ortamını hazırlamak amacıyla halkın seçimi ile oluşturulan ilk meclis olan Muhassıllık Meclisleri kurulmuştur. Muhassıllık Meclisleri, Tanzimat'nn öngörmüş olduğu mali alanda merkeziyetçiliği sağlamak adına yapılan bir sistemdir. Bu meclislerin kurulmasındaki amaç, iltizam sisteminin kaldırılması sonucu vergi toplama işlevi neticesinde oluşan boşluğa bir son vermek ve bu fonksiyonu valilerin ve yerel ayanların elinden alarak kötü uygulamalara son vermektir. Tanzimat Fermanı ile gerçekleştirilen düzenlemeler bir yerinden yönetim adımı olmaktan ziyade, içinde bulunulan zaman ve koşulların gerekliliğini yerine getirerek ihtiyaç duyulan reformları gerçekleştirmek olarak nitelendirilebilir. Ancak bu dönem, kamu yönetimi sisteminin yeniden dizaynı ve bununla beraber yerel yönetim sisteminin temellerinin atıldığı dönem olarak karşımıza çıkmaktadır (Ortaylı, 1985: 33).

1876 Kanuni Esasi ile il özel idaresi, özerk bir yerel yönetim idaresi haline gelmiş ve anayasal kimlik edinmiştir (Duran, 2009: 2). Kanuni Esasi'nin 108. maddesinde "vilayetlerin usulü idaresi tevsii mezuniyet ve tefriki vezaif kaidesi üzerine müesses" olduğu hükmü getirilerek taşra idaresinde "yetki genişliği ve görevler ayrılı̆̆ı" ilkeleri kabul edilmiştir. Bununla birlikte bu maddenin yürürlüğe girmesi ile birlikte taşra yönetiminin derecelerinin özel nizamnameler ile düzenleneceği açılanmıştır. İller ve kaza merkezlerinde idare meclisi ve vilayet merkezlerinde de umumi meclisler kurularak bu meclislerin oluşumları da özel nizamnameler ile yapılmıştır. 1876 Anayasası ile birlikte taşra idaresinde mevzuat aşamasında ciddi bir gelişme yaşanmıştır. "Tevsii mezuniyet (yetki genişliği)" ve “tefriki vezaif (görevler ayrılığı)" ilkeleri mevzuata dâhil edilmiştir (Kartal, 2013: 18).

1864 Vilayet Nizamnamesi 1870 y1lına kadar uygulanmış ve yerini İl özel idaresi 1913 tarihli İdare-i Umumiye-i Vilayet Nizamnamesi'ne bırakmıştır. Nizamname'de, vilayetlere tüzel kişilik verilmediği için, o dönemde(1864-1870) vilayetler yerel yönetim birimi olarak ifade edilmemektedir. Yerel yönetim birimi olmaları yönünde yasal adım 1876 Kanunu Esasi ile atılmasına rağmen tam anlamıyla bir yerel yönetim birimi 1913 tarihli Kanun ile olmuştur (Parlak, 2015: 72-73). Cumhuriyet dönemine bu Kanun ile devredilen il özel idareleri, 1987 yllına kadar 1913 tarihli Kanun ile yönetilmiş, 1930 yılında ise 10 maddelik bir değişiklik yapılmıştır (Parlak ve Ökmen, 2015: 195).

1987 tarihinde İdare-i Umumiye-i Vilayet Nizamnamesi’nin adı değiştirilerek "3360 sayılı İl Özel İdaresi Kanunu" olmuştur. 3360 sayılı Kanunda il özel idaresine verilen görev ve sorumlulukların yerine getirilebilmesi için yeni bir düzenleme yer almamaktadır. Netice itibariyle 1913 tarihli Kanunun hükümleri yapı itibariyle 3360 sayılı Kanun'da değiştirilmemiştir (Hakyemez, 1998: 173-174). 3360 sayılı Kanun, il özel idaresine eğitim ve öğretim, sağlık ve sosyal yardım, bayındırlık, tarım ve hayvancılık ve iktisadi ve ticari alanlarda çok önemli görevler vermiştir(Aytaç, 1995: 385). Fakat geçmiş dönemlerde personel azlığ1, yeterli ölçüde maddi kaynaklara sahip olmamak ve bu görev ve sorumlulukların merkezi yönetim tarafından yerine getiriliyor olmasından dolayı, il özel idaresi kanununda il özel idaresine verilen görev ve sorumlulukların ancak küçük bir kısmını yerine getirmiştir (Eryllmaz, 2004: 126). Bu durum il özel idaresinin görevinin sona ermesi ve kaldırılması gerektiğini düşünen görüşlerin ortaya çıkmasına neden olmuştur (Aytaç, 1995: 385). Dolayısıyla hukuksal bir karışıklığa sebep olmuştur. Çünkü bazı kanunlarla merkezi yönetim 
kuruluşlarına verilen görevler il özel idaresi kanunundan çıkarılmamıştır. Aynı görev tanımında hem merkezi idare hem de il özel idaresi yetkili olmaya başlamıştır. Bu yüzden merkezi idare ile il özel idaresi arasında sağlıklı bir görev tanımı ve bölüşümü yapılması gerekmektedir (Yavuz, 1966: 148).

1913 yılından 1980'li y1llara kadar geçen zaman dilimi içinde yaşanan siyasi, idari, ekonomik ve sosyal birçok değişikliğe rağmen, il özel idaresi bu değişime entegre olacak bir yapıya kavuşturulamamıştır. İl özel idaresi ile ilgili olarak 1987 yılında yapılan değişiklikler de mevcut konu ve sorunlara çözüm getirememiştir (Ertabak, 1998: 309-310). 3360 sayıll Kanun ile getirilen yeniliklerin de sorunlara çözüm getirmemesi, il özel idaresi ile ilgili mevcut tartışmaları kronikleştirmiştir. İl özel idarelerinin kronikleşen sorunları hep belli başlı konular çerçevesinde gündeme gelmiştir (Nadaroğlu, 2001: 188). İl özel idaresinin 3360 sayılı Kanun kapsamındaki görevlerini ifası konusunda önemli bilgiler veren İçişleri Bakanlığı İç Düzen Genel Raporu'nda da; sağlık hizmetlerinin hemen hemen hiç yapılmadığını, tarımla ilgili görevlerin yerine getirilemediği, bayındırlık görevlerinde görev dağılımı, teşkilat ve personel yetersizliği, mali yetersizlikler gibi sebeplerle eksiklikler olduğu vurgulanmıştır (Keleş, 2000: 45).

İl özel idaresi son olarak 22.02.2005 tarihli 5302 sayılı İl Özel İdaresi Kanunu ile düzenlenmiştir. $\mathrm{Bu}$ kanun ile il özel idaresi geçmişe kıyasla daha fonksiyonel, geniş bir örgütsel yapıya kavuşturulmuştur. İl özel idaresinin yeni yapısıyla alakalı ilk dikkat çeken husus yönetim organlarının sıralanması ile ilgilidir. Bu değişikliğe göre önceki kanunda ilk sırada olan vali, son sıraya getirilmiştir. En önemli değişikliklerden birisi de valinin il genel meclisi(İGM) başkanlığ1 görevinin validen alınarak, meclisin kendi içinden seçeceği bir kişiye verilmesi olmuştur. İGM bu idarelerin en önemli organı haline gelmiştir. Ayrıca 3360 sayılı Kanuna göre vali tarafindan belirlenen toplantıların gündemi 5302 sayılı Kanun ile meclis başkanı tarafından belirlenecektir. Böylece vali, İGM'den soyutlanmış olmakta ve karar alma sürecine katılmadığı kararları uygulamak durumunda kalmaktadır (Güzel,2010: 97).

İl özel idaresine verilmiş olan bazı görevler esasen idarelerin bu görevleri yerine getirebilecek seviyede mali güce ve personel kadrosuna sahip olamamasından kaynaklı olarak yalnızca kâğıt üzerinde kalan bir duruma dönüşebilmektedir. Bu sebeplerle il özel idaresi aracıllğıyla yürütülmesi gereken görev ve hizmetler zaman içerisinde merkezi yönetim tarafından üstlenilmek zorunda kalmıştır. Bu durum da il özel idaresinin güçsüzleşmesine yol açmaktadır. Stratejik plan ile il özel idaresi faaliyetlerinin ve personelinin performans ölçütlerini görüşmek ve karara bağlamak; norm kadro çerçevesinde il özel idaresinin ve bağlı kuruluşlarının kadrolarının ihdas, iptal ve değiştirilmesine karar vermek, ihtisas komisyonları üyelerini seçmek yer almaktadır. Ayrıca yurt içindeki ve yurt dışındaki yerel yönetim birimleri ve yerel yönetim birlikleriyle karşılıklı işbirliği yapılmasına karar vermek; meclis başkanı, başkan vekilleri ve kâtip üyeleri seçmek; ilin çevre düzeni planı ile belediye sınırları dışındaki imar planlarını görüşmek ve karara bağlamak 5302 sayılı Kanun ile İGM'ye yüklenen yeni görevlerdir. 5302 sayılı Kanun, il özel idaresinin diğer yerel yönetim birimleriyle birlik kurmasına ve kurulmuş birliklere katılmasına tam yetki vermiştir. Bu konudaki kararı IGM vermektedir (Altıntaş, 2007: 38).

5302 sayılı Kanun, kamu hizmetlerinin sürekli, etkin ve verimli sunulabilmesi amaciyla yetki devrine imkân tanımaktadır. Bu düzenlemeye göre, vali yardımcıları il özel idaresinin yönetiminde söz sahibi olamayacaklardır. Bununla birlikte encümene verilmiş olan valinin aylık harcamalarını inceleme görevinin, 5302 sayılı Kanun ile ortadan kalktığ 1 görülmektedir. Bunun muhtemel sebebi, İGM'nin her ay toplanması ve hem toplantıda harcamaları denetleyebilmesi hem de harcamaların denetim komisyonu tarafından denetlenmesidir. Encümen kararlarının vali tarafından geri gönderilmesi durumunda 2/3 oranında diretilmesi halinde kesinleşiyor olmasına karş1lık, 5302 sayılı Kanun ile $2 / 3$ yerine salt çoğunluk yeterli görülmüştür. İl özel idaresi teşkilat yapısı ile ilgili olarak genel sekreterlik ve norm kadro uygulamas1 gibi önemli düzenlemeler bulunmaktadır. İl özel idare teşkilatında yeni olan genel sekreter, il özel idaresi hizmetlerini vali adına ve onun emirleri ile

Turkish Studies - Economics, Finance, Politics

Volume 14 Issue 2, 2019 
gerçekleştirmektedir. 3360 sayılı Kanun'a nazaran il özel idaresi için daha özerk bir yapı oluşturmaya çalışıldığ1 görülmektedir (Güzel,2010: 99).

5302 say1l Kanun ile verilen yetkiler arasında en önemli unsurlardan bir tanesi hizmet alanları ile ilgili olarak yönetmelik çıkarabilme yetkisinin tanınmış olmasıdır. Bu durumda il özel idaresi hizmet alanlarına ilişkin olarak yönetmelik çıkararak yerel ve bölgesel sorunlarla ilgili ortaya çıkabilecek sorunları kısa zamanda bertaraf etme imkânı bulmuştur. İl tüzel kişiliğine verilen görevler arasına giren tüm işler, İGM'nin yetki alanı içindedir bu nedenle bu işler hakkında karar alma yetkisi de meclise verilmiştir. İGM kararlarının valinin onayı yerine İGM'nin kabulüyle yürürlüğe girmesi ve il özel idaresi bütçesinin İçişleri Bakanlığı'nın onayı yerine İGM'nin kabulüyle yürürlüğe girmesi İGM'ye 5302 sayılı Kanun ile getirilen önemli yeniliklerdendir (Giritli vd., 2001: 227). Yapılan bu yenilikler şu şekilde özetlenebilir:

- Yönetim organları sıralamasında valinin ilk sıradan son siraya getirilmesi,

- İl Genel Meclisi Başkanının vali yerine meclisin kendi içerisinden seçimle belirlenmesi,

- İl genel meclisi toplantı gündem belirleme yetkisinin validen meclis başkanlığına geçmesi,

- İl özel idaresi hizmet alanları ile ilgili yönetmelik çıkarma yetkisine haiz kılınması,

- Genel sekreterlik makamının oluşturulması,

- İl özel idarelerinin idari ve mali açıdan özerk yerel yönetim birimi olarak tanımlanması,

- Norm kadro uygulamasının oluşturulması.

İl özel idaresi, kendisine verilen görevleri gerçekleştirebilmek amacıyla bir takım yetki ve imtiyazlarla donatılarak bazı muafiyetlere de sahip kılınmaktadır. 5302 sayılı il özel idaresi Kanunu'nun 7. maddesinde bu yetki ve imtiyazlar şunlardır (Ulusoy, 2005: 193-194):

- "Kanunlar ile verilen hizmetleri ve görevleri yerine getirebilmek adına her türlü çalışmaları gerçekleştirmek, gerçek ve tüzel kişiler için Kanunlarda yer alan izinleri ve ruhsatları vermek ve denetimini sağlamak

- Kanunların il özel idaresine vermiş olduğu yetki dahilinde yönetmelik çıkartmak, emir ve yasaklar koymak, Kanun çerçevesinde cezai işlemler uygulamak.

- Hizmetlerin gerçekleştirilmesi amacıyla taşınır ve taşınmaz malları almak, kiralayabilmek veya kiraya vermek, bunlar üzerinde sınırlı aynî hak tesis etmek.

- İl özel idaresinin menfaatleri doğrultusunda bağışları kabul etmek ve borç almak.

- Vergi, resim ve harçlar dışında kalan ve miktarı yirmi beş milyar Türk Lirasına kadar olan dava konusu uyuşmazlıkların anlaşmayla tasfiyesine karar vermek.

- Özel Kanunları gereğince il özel idaresine ait vergi, resim ve harçların tarh, tahakkuk ve tahsilini yapmak.

- Belediye sınırları dışında yer alan gayri sıhhî işletmeler ile umuma açık istirahat ve eğlence yerlerinin ruhsat verilmesini gerçekleştirmek ve denetlenmesini sağlamak. Ancak sivil hava ulaşımına açık havaalanları bünyesinde yer alan tüm tesislere işyeri açma ve çalışma ruhsatı dâhil her türlü ruhsat, Sivil Havacılık Genel Müdürlüğü tarafından verilir. Bu konuya ilişkin usul ve esaslar Sivil Havacılık Genel Müdürlügünce hazırlanacak bir yönetmelikle düzenlenir.”

2012 yılında çıkarılan 6360 sayılı Kanun ile il özel idarelerine ilişkin köklü bir değişiklik yapılmıştır. Bu kanun kapsamında büyükşehir sayıs1 30'a çıkarılarak, büyükşehirlerdeki il özel idareleri kapatılmıştır. Kapatılan il özel idaresinin görev ve sorumluluklarının bazıları büyükşehir 
belediyesine devredilirken bazı görev ve sorumluluklarının ifası için Yatırım İzleme ve Koordinasyon Başkanlıkları kurulmuştur. Cumhurbaşkanlığı Hükümet Sistemine geçilmesiyle birlikte ise, çıkarılan 1 Numaralı Cumhurbaşkanlığı Teşkilatı Hakkında Cumhurbaşkanlığı Kararnamesi ile Yatırım İzleme ve Koordinasyon Başkanlığı tüzel kişiliğe kavuşturularak kamu tüzel kişiliğini haiz ve özel bütçeli yapılar haline gelmiştir.

Yatırım İzleme ve Koordinasyon Başkanlıkları aşağıda belirtilen müdürlüklerden oluşmaktadır. Bunlar (28962 sayılı Yönetmelik, 4. Madde):

a) Yatırım İzleme Müdürlüğ̈̈.

b) Rehberlik ve Denetim Müdürlüğü.

c) Strateji ve Koordinasyon Müdürlüğü.

d) 112 Acil Çağrı Merkezi Müdürlüğü.

e) İdari ve Mali İşler Müdürlüğü.

f) Hukuk İşleri Müdürlüğü.

g) Doğal Kaynaklar, Ruhsat ve Kültür Varlıkları Müdürlüğü.

İlgili yönetmeliğe göre, Başkanlık ihtiyaç gördüğü konularda bünyesinde valinin onayıyla geçici birimler kurabilme yetkisine sahiptir. Ayrıca, ihtiyaç durumunda valinin onayıyla Başkanlığın görevlerini gerçekleştirebilmek amaciyla ilçelerde de geçici birimler kurulabilmektedir. Başkan, geçici birimlerin yönetimini sağlamak için birim sorumlusu görevlendirebilmektedir.

YİKOB'lar büyükşehir olan illerde merkezi idarenin ya da diğer kamu kurum ve kuruluşlarının ilde yapacakları hizmet veya yatırımların verimliliğini ve etkinliğini denetleyen ayrıca gerektiğinde koordinesini sağlayan, ilin tanıtımından sorumlu, afet, acil durum ve acil yardım gibi durumlarda koordineyi sağlayan, temsil, tören ve protokol işlemlerini yürüten bir kurum olarak kurulmuştur (3152 sayılı İçişleri Bakanlığı Teşkilat ve Görevleri Hakkında Kanun, 28. Madde). Ayrıca, ilin tanıtımı, ildeki kamu kurum ve kuruluşlarına yol gösterilmesini ve bunların denetlenmesini gerçekleştireceklerdir (CBK-1, 273. Madde).

YİKOB'lar valiliğe bağlı ve valilik başkanlığında çalışacak yeni bir merkezi yönetimi birimi olarak görevleri il özel idareleri ile kıyaslandığında oldukça azalmıştır. İl özel idarelerinin yetkilerinin büyük bir çoğunluğu büyükşehir belediyelerine devredilmiştir. Yatırım İzleme ve Koordinasyon Başkanlıkları'nın görevleri şunlardır (28962 sayılı Yönetmelik, 25. Madde):

- "Kamu kurum ve kuruluşlarının yatırım ve hizmetlerinin etkin olarak yapılmasını, izlenmesini ve koordinasyonunu sağlamak,

- Merkezi idarenin adli ve askeri teşkilatı dışındaki taşra birimlerinin yürüttükleri hizmet ve faaliyetlerin etkinlik, verimlilik ve stratejik plan ve performans programlarına uygunluk açısından değerlendirildiği raporu hazırlamak ve valinin değerlendirmesi ile birlikte Başbakanlı̆̆a ve ilgili bakanlıklara göndermek,

- Maden veya jeotermal ve doğal mineralli su kaynaklarının bulunduğu yere en yakın yerleşim yerlerinin altyapı ve yöresel müşterek ihtiyaçlarında kullanılmak üzere Bakanlık bütçesinden Başkanlı̆̆a aktarılan ödenekleri kullanmak,

- Tüzel kişilikleri kaldirllan il özel idarelerine, Jeotermal Kaynaklar ve Doğal Mineralli Sular Kanunu, Maden Kanunu ve Kültür ve Tabiat Varlıkların Koruma Kanunu'nun ilgili maddeleri kapsamında verilen her türlü görevi yapmak ve kullanmak,

- Temsil, tören, ödüllendirme ve protokol hizmetlerini yürütmek, 
- Afet ve acil yardım hizmetlerini koordine etmek ve yürütmek,

- İlin tanitımına yönelik faaliyetleri yürütmek ve koordine etmek,

- 112 acil çağr hizmetlerini koordine etmek ve yürütmek,

- İldeki kamu kurum ve kuruluşlarına rehberlik etmek ve bunları denetlemek,

- Kamu kurum ve kuruluşlarının bürolarının ihtiyaçlarını ödenek durumuna göre karşılamak,

- Kamu kurum ve kuruluşlarının Taşıt Kanunu kapsamındaki araçlarının alımı, işletilmesi, bakım ve onarımını ödenek durumuna göre yapmak veya yaptırmak,

- Merkezi idare tarafindan yapılan her türlü yardımı koordine etmek, denetlemek, izlemek ve acil durumlarda bizzat yerine getirmek,

- Hükümet konaklarının, Başkanlığa tahsisli binaların, lojmanların, valilik ve kaymakamlık konutlarının yapım, bakım, işletme, tefrişat ve onarımını sağlamak ve ihtiyaçları karşılamak,

- Emniyet hizmetlerinin gerektirdiği harcamaları ödenek durumuna göre yapmak,

- İldeki kamu kurum ve kuruluşlarınca yürütülmesi gereken yatırım ve hizmetlerin aksadığının ve bu durumun halkın sağhl̆ğ, huzur ve esenliği ile kamu düzeni ve güvenliğini olumsuz etkilediğinin vali veya ilgili bakanlığınca tespit edilmesi durumunda, hizmet ve yatırımın gerçekleştirilmemesi halinde söz konusu yatırım ve hizmetleri, valinin talimat ile yerine getirmek,

- Gerektiğinde merkezi idarenin taşrada yapacağı yatırımları yapmak ve koordine etmek,

- Muhtar ödenekleri ile ilgili iş ve işlemleri yapmak,

- Kamu kurum ve kuruluşlarınca yürütülmesi gereken yatırım ve hizmetlerin gerektirdiği araç, gereç, makine, bina ve tesisleri kiralamak,

- Valinin vereceği diğer görevleri yapmak."

Başkanlığın yönetimi, vali veya vali tarafından görevlendirilen vali yardımcısı vasıtasıyla gerçekleştirilmektedir. YIKKOB'a ildeki kamu kurum ve kuruluşlarının denetimi açısından da önemli bir görev verilmiştir. Bu çerçevede: "merkezi idarenin adli ve askeri teşkilat dişında taşradaki tüm birimlerinin hizmet ve faaliyetlerinin etkinliği, verimliliği ve kurumların stratejik plan ve performans programlarına uygunluğu ile ilgili hazırlanacak rapor, valinin değerlendirmesiyle birlikte Cumhurbaşkanlığına ve bu kurumların bağlı veya ilgili olduğu bakanlığa gönderilir”(CBK-1, 273 Madde).

YİKOB'lara görev ve sorumluluklarını etkin bir şekilde yerine getirebilmeleri amacıyla; "afet yardım, acil çağrı, yatırım izleme, rehberlik ve denetim, strateji ve koordinasyon ile idari müdürlükler" kurabilme yetkisi tanınmıştır (CBK-1, 273. Madde). Bu çerçevede YİKOB'ların teşkilat şemalarında önceden müdürlükler teknik ve idari müdürlükler olarak gösterilirken, şu anda sadece müdürlükler olarak gösterilmektedir (Akman ve Kalender, 2018: 1030). Ayrıca, YİKOB'lara gereken durumlar için geçici birimler kurulabilme yetkisi de verilmiştir. Madde):

YİKOB'ların işleyişi ile ilgili diğer önemli hususlar şu şekilde özetlenebilir (CBK-1, 273

- "Yatırım izleme ve koordinasyon başkanlıklarının çalışma usul ve esasları İçişleri Bakanlığınca çıkarılan yönetmelikle belirlenir. 
- Başkanlığın gelirleri İçişleri Bakanlığı bütçesinden yapılacak Hazine yardımları, kamu kurum ve kuruluşlarının yatırım ve hizmetleri için aktardıkları tutarlar, bağış ve yardımlar ve diğer gelirlerdir.

- Başkanlığa verilen görevlerin gerektirdiği her türlü giderler Başkanlık bütçesinden karşılanır. karşılanır.

- Başkanlığın personel ihtiyacı İçişleri Bakanlığı kadrolarında görev yapan personelden

- Gerektiğinde valilik, kadro, yer ve unvanlarına bakılmaksızın ihtiyaç durumuna göre uzman, sözleşmeli personel ve memurları bu başkanlıklarda görevlendirmeye yetkilidir.

- Başkanlığın bütçesinin hazırlanması ve uygulanması ile diğer hususlar Strateji ve Bütçe Başkanlığının görüşü alınarak Bakanlık tarafından çıkarılan yönetmelikle belirlenir.

- Başkanlık ilin ihtiyaçları çerçevesinde gerektiğinde her türlü yatırım ve hizmetleri yerine getirebilir; bu amaçla kamu kurum ve kuruluşlarıyla, diğer tüzel kişilerle ve sivil toplum kuruluşlarıyla işbirliği yapabilir ve ortak projeler yürütebilir."

İl özel idaresinin kuruluş kanunu olarak kabul edilen1864 Vilayetler Nizamnamesi'nden günümüze tam 155 yıl geçmiştir. Bu süre zarfında il özel idaresinin görev ve sorumlulukları çeşitli kanunlarla revize edilmiştir. Bu değişikliklerden ilki 1987 yılında çıkarılan 3360 sayılı Kanun, ikincisi ise 2005 yılında çıkarılan 5302 sayılı Kanundur. 5302 sayılı Kanun ile il özel idaresinin yapısında oldukça önemli değişiklikler yapılmış, yapılan bu değişiklikler çalışmada maddeler halinde sunulmuştur. İl özel idaresi ile alakalı son olarak 2012 yılında çıkarılan 6360 sayılı Kanun ile bazı değişiklikler yapılmış ve yapılan değişiklikler neticesinde 30 ilde il özel idaresi kaldırılmıştır. Osmanlı Devleti'nden günümüze miras kalan bu kurumun 30 ilde kaldırılması ve bazı görev ve sorumlulukların YİKOB'a devredilmesi, YİKOB'un bu görev ve sorumlulukları yerine getirip getiremeyeceği gibi bazı soruları ortaya çıkarmıştır. Ayrıca, hem2005 yılında yapısında önemli değişiklikler yapılan il özel idaresinin aradan kısa süre geçmesinden sonra 6360 sayılı Kanun ile 30 ilde kapatılması, hem de yeni yönetim sistemi ile sonradan tüzel kişilik kazandırılması dikkat çekmektedir.

\section{Ege Bölgesi Yatırım İzleme ve Koordinasyon Başkanlıkları Üzerine Bir İnceleme}

\section{1. Çalışmanın Amacı, Kapsamı, Yöntemi ve Soruları}

Çalışmada YİKOB'ların teşkilat yapısı, görev, yetki ve sorumlulukları, mali yapısı ve denetimi ve bu yeni kurumun YİKOB başkanları ve yöneticileri tarafından nasıl görüldüğü araştırılmıştır. Çalışmanın evreni Türkiye'deki tüm büyükşehir illeridir. Örneklemi ise Ege Bölgesi'ndeki tüm büyükşehir illeridir. Çalışmanın örneklemi doğrultusunda Ege Bölgesi'ndeki tüm YIKKOB'larla nitel bir araştırma tekniği olan mülakat yöntemi kullanılmıştır. Aydın, Muğla, Denizli, Manisa ve İzmir olmak üzere toplamda 5 ilde 4'er yöneticiden randevu talep edilmiş, 19 yönetici ile mülakat yapılabilmiştir. Mülakat yapılan yöneticiler;YİKOB Başkanı, İdari ve Mali İşler Müdürü, Strateji ve Koordinasyon Müdürü ve Yatırım İzleme Müdürü şeklindedir.

Çalışma kapsamında Ege Bölgesi’ndeki tüm büyükşehir illeri ziyaret edilmiş ve YİKOB başkanları ve yöneticileriyle görüşmeler gerçekleştirilmiştir. Görüşmeler Ağustos 2017'de yapılmış ve ortalama 35 ile 65 dakika arasında gerçekleşmiştir. Araştırma esnasında görüşülen YİKOB başkanları ve yöneticilerinin görüş belirtirken çekincelerinin olduğu gözlemlenmiştir. Görüşme gerçekleştirilen YİKOB başkanları ve yöneticilerinin tümü YİKOB'un gelişimi için önerilerini paylaşmışlardır. Ayrıca YİKOB'daki mevcut olumsuzlukların giderilebilmesi için çalışmayı oldukça önemsedikleri gözlemlenmiştir. Özellikle çalışmada isim paylaşılmayacağı bilgisinin üzerine çok daha detaylı bilgiler edinilebilmiştir. Görüşme gerçekleştirilen tüm YİKOB'larda eleştiri yapan yönetici sayısı memnun olan yönetici sayısından fazladır. Genel olarak YİKOB'larda görüşülen başkan ve yöneticiler kapatılan il özel idaresinin eski yöneticileridir. $\mathrm{Bu}$ durum kıyas yapmalarını daha da 
kolaylaştırmaktadır. Ayrıca, görüşülen tüm yöneticiler erkek, yaş aralığı 35-55 arasında ve eğitim durumu en az lisans seviyesindedir.

Görüşme formunda toplam 15 adet soru yer almaktadır. Bu sorular şu şekildedir:

1. Sizce YİKOB neden kuruldu? Büyükşehirlerde il özel idarelerinin kaldırılmasını gerektiren unsurlar sizce nelerdir ve bu değişikliği nasıl değerlendiriyorsunuz?

2. İl özel idaresi ile YİKOB'un olumlu ve olumsuz yönleri nelerdir?

3. YİKOB'un daha işlevsel hale gelebilmesi için sizce yapılması gereken temel düzenlemeler nelerdir?

4. Sizce tüm illerde il özel idareleri kaldırılarak yerine YIKKOB'lar kurulmalı mıdır?

5. İl özel idaresi organı olan il genel meclisi seçimle oluşturulurken, YİKOB atama yoluyla oluşturulmaktadır. Yerel demokrasi bağlamında Bu değişikliği nasıl değerlendiriyorsunuz?

6. YİKOB'lar il özel idaresinin kaldırılması ile doldurması gereken boşluğu doldurabiliyor mu? Bu boşluklardan kısaca bahseder misiniz?

7. YíKOB'ların kurulmasının yerellik ilkesi ile bağdaşmadığı eleştirileri hakkında ne düşünüyorsunuz?

8. Sizce YİKOB'a neden tüzel kişilik kazandırılma ihtiyacı duyuldu?

9. Büyükşehir belediyelerinin bulunduğu illerdeki yatırım ve hizmetlerin etkin olarak yapılması, izlenmesi ve denetlenmesi yapılırken nelere dikkat edilmektedir?

10. YİKOB'ların denetimi ile ilgili 6360 sayılı Kanun ve sonrasında çıkan ilgili kanunlarda herhangi bir bilgi bulunmamaktadır. Denetimi ile alakalı bilgi verir misiniz?

11. YIKKOB'larda başlangıçta bulunan idari ve teknik müdürlük ayrımının ortadan kaldırıldığını görmekteyiz. Bu konu hakkında bilgi verir misiniz?

12. Vali ve büyükşehir belediye başkanları arasındaki ilişkilerde bir değişiklik oldu mu? Büyükşehir belediye başkanlarının yetki ve sorumluluklarındaki artış güç çatışmasına neden olabilir mi?

13. İçişleri Bakanlığı'nın YİKOB olarak sunduğunuz önerileri dikkate aldığını düşünüyor musunuz?

14. Yillardır valinin de seçimle gelmesi ile ilgili tartışmalar devam ediyor. Bu konuda ne düşünüyorsunuz?

Son soruda ise eklemek istedikleri düşüncelerinin var olup olmadığı sorulmuştur. Böylece, görüşülen kişilerin konu ile ilgili farklı düşüncelerine de yer verilmesi amaçlanmıştır.

\section{2. Çalışma Bulgularının Değerlendirilmesi}

Çalışmada ilk olarak YİKOB'un neden kurulduğu, kuruluş amacına uygun yetki ve sorumluluklarının olup olmadığı ve bu çerçevede YİKOB kurulmasını olumlu karşılayıp karşılamadıkları sorusu yöneltilmiştir. Tablo 1'de görüldüğü üzere Aydın yöneticileri arasında YİKOB'un kurulmasına olumlu bakan yönetici olmazken Muğla ve Manisa illerinde 2'şer yönetici YIKOOB'un kurulmasına olumlu bakmaktadır. Manisa ve Denizli'de ise olumlu bakan yönetici sayısı sadece 1'er tanedir. Görüşülen yöneticilerin sadece 6'sı YIKKOB'un kurulmasını olumlu karşılamaktadır. Buna karşın olumsuz bakan yönetici sayısı ise 11 olarak dikkat çekmektedir. Çekimser kalan 2 yönetici ise kararın bir siyasi otorite tarafından alındığını belirtip fikir belirtmek istememişlerdir. 


\begin{tabular}{|c|c|c|c|}
\hline \multicolumn{5}{|c|}{ Tablo 1. YİKOB Kurulması Hakkındaki Genel Görüşler } \\
\hline Görüșülen İller & Olumlu & Olumsuz & Çekimser \\
\hline Aydın & - & 3 & 1 \\
\hline Denizli & 1 & 3 & - \\
\hline İzmir & 2 & 2 & 1 \\
\hline Manisa & 1 & 2 & $\mathbf{2}$ \\
\hline Muğla & 2 & 1 & $\mathbf{1 1}$ \\
\hline TOPLAM & $\mathbf{6}$ & & \\
\hline
\end{tabular}

İkinci olarak il özel idaresi ile YİKOB'un olumlu ve olumsuz yönleri nelerdir? Sorusu sorulmuştur. Tablo 2'de görüldüğü üzere görüşülen yöneticilerin 11'i il özel idaresini, 5'i YİKOB'u olumlu görmektedir. 3 yönetici ise çekimser kalmıştır. Burada dikkat çeken en önemli husus Aydın'da görüşülen yöneticilerin tamamının il özel idaresini olumlu görmesidir.

Tablo 2.İ̈İ ve YİKOB ile İlgili Görüşler

\begin{tabular}{|c|c|c|c|}
\hline Görüşülen İller & İÖI & YİKOB & Çekimser \\
\hline Aydın & 4 & - & - \\
\hline Denizli & 1 & 1 & 2 \\
\hline İzmir & 3 & 1 & \\
\hline Manisa & 2 & 1 & 1 \\
\hline Muğla & 1 & 2 & $\mathbf{3}$ \\
\hline TOPLAM & $\mathbf{1 1}$ & $\mathbf{5}$ & \\
\hline
\end{tabular}

İl özel idaresini avantajlı gören yöneticilerin gerekçeleri şunlardır:

- $\quad$ Köklü bir kurum olması dolayısıyla teamüllerinin belirgin olması,

- $\quad$ Gelir elde edici faaliyetlerde bulunabilmesi ve gelir elde edebilmesi,

- $\quad$ Elde ettiği gelirlerle yatırım yapabilir durumda olması,

- Görev tanımının belirgin olması, görev tanımına uygun personel istihdam etme hakkının olması ve yeterli teknik personelinin bulunmas1,

- Malvarlığı açısından zengin bir kurum olması,

- İl özel idaresinin kırsal kesimde kalkın(dır)ma yönünün de bulunması,

- Yatırım kararlarının seçilmiş kişiler tarafından alınıyor olmasının yerel demokrasi ve yerellik ilkesi ile uyumlu olmas1,

- Bürokrasinin oldukça az olması ve taleplere çok hızlı cevap verebilecek imkânı olması.

YİKOB'u avantajlı gören yöneticilerin gerekçeleri ise şunlardır:

- Merkezi idarenin ildeki yatırımlarının tek elden yapılıyor olması,

- Siyasallaşabilecek bir karar organının bulunmaması,

- Tüzel kişiliği sayesinde ödeneklerin yılsonunda tenkis olmaması,

- İl özel idaresine kıyasla daha az personelle daha hızlı sürede iş yapıyor olması,

- Güçlü ve geniş yetkileri olan bir kurum olması,

- Geçici personel görevlendirmesi sayesinde personel yığılmalarının engellenmesi,

- İldeki tüm yatırımların tek merkezden gerçekleşmesi sonucunda her bakanlığın taşra teşkilatında teknik personel bulunma gerekliliğini ortadan kaldırıyor olması. 
Çalışmada üçüncü olarak yöneticilere, YİKOB'un daha işlevsel hale gelebilmesi için neler yapılması gerektiği sorusu yöneltilmiştir. Bu çerçevede Tablo 3, beş ilde görüşülen tüm yöneticilerin önerilerinden ortaya çıkan ortak fikirler doğrultusunda oluşturulmuştur. Görüşülen tüm yöneticiler personel alım yetkisinin olması gerektiğini önermişlerdir. Bunun sebebi bazı YİKOB'larda dava dosyalarını takip edecek avukatın ve inşaat yapı gibi teknik iş ve işlemlerin takibini yapacak mühendisin olmamasıdır. İkinci olarak, yönetmeliğin daha anlaşılır hale getirilmesini önermişlerdir. Bunun sebebi de bazı yetki ve sorumluluklarının hangi kapsamda gerçekleştirilmesi gerektiğinin tam olarak ortaya konulmamasidır.

Tablo 3. YİKOB'un İşlevselliği Hakkında Genel Görüşler

\begin{tabular}{|c|c|c|c|}
\hline Görüşler & Evet & Hayır & Çekimser \\
\hline Personel Alım Yetkisinin Olması & 19 & - & - \\
\hline Yönetmeliğinin Daha Anlaşılır Hale Getirilmesi & 14 & - & 5 \\
\hline Başkanının Mühendis Kökenli Bir Vali Yardımcının Olması & 14 & - & 5 \\
\hline Gelirlerinin Oluşturulması & 15 & & 4 \\
\hline Tamamen Özerk Bir Kurum Olması & 15 & - & 4 \\
\hline
\end{tabular}

YİKOB'un daha işlevsel hale getirilebilmesi için ortaya çıkan öneriler şunlardır:

- $\quad$ YİKOB'a personel istihdam etme yetkisi verilebilir. Ama bu yetki nepotizme sebep olmamalıdır.

- Genel olarak kurumun tanımı, görevleri, yetkilerinin gözden geçirilmesi ve netleştirilmesi, kurum çalışma usul ve esasları için fayda sağlayacaktır.

- İl özel idaresinden belediyeye geçen malların bir kısmının YİKOB'a devredilmesi, YİKOB'ların yatırım yapabilmesine yardımcı olabilir.

- Kurumdaki geçici görevlendirmelerin son bulup, kurum personelinin istihdam edilmesi fayda sağlayabilir.

- İlçelerde YİKOB'ların temsilciliklerinin kurulması daha aktif faaliyet göstermesine yardımcı olabilir.

- $\quad$ İl özel idaresi gibi özerk bir kurum haline getirilebilir.

- $\quad$ Harcama yetkisinin teknik müdürlüklerde olması bürokrasiyi azaltabilir.

- $\quad$ Fiziki ortam yetersizliği olan illerde, bu eksikliğin giderilmesi, personelin çalışma motivasyonuna ve verimliliğine olumlu katkı sağlayabilir.

- Kendi kuruluş kanunun olması faaliyet gösterebilmesi adına yararlı olabilir.

- YİKOB'lar vergi gelirlerinden pay alabilir, böylece yatırım yetkisini daha etkin olarak kullanabilir.

Çalışmada dördüncü olarak büyükşehirlerde il özel idarelerinin kapatılması, görev ve sorumluluklarının YİKOB ve büyükșehir belediyeleri arasında paylaştırılması, büyükșehir olmayan 51 il için uygulanabilirliği sorulmuştur. Görüşülen illerdeki yöneticiler bu sorunun İçişleri Bakanlığı'nın da görüş almak için kendilerine sordukları sorulardan birisi olduğunu vurgulamışlardır. Tablo 4 'te görüldüğü üzere görüşülen yöneticilerin sadece 4'ü bu değişikliği desteklemektedir. 2 kişi bu konuda çekimser kalırken, 13 kişi il özel idaresinden YİKOB'a geçişi desteklememektedir. 
Tablo 4. Tüm İllerde YİKOB kurulması Hakkında Genel Görüşler

\begin{tabular}{|c|c|c|c|}
\hline Görüsülen İller & Evet & Hayır & Çekimser \\
\hline Aydın & - & 3 & 1 \\
\hline Denizli & 1 & 3 & - \\
\hline İzmir & 1 & 3 & \\
\hline Manisa & - & 3 & 1 \\
\hline Muğla & 2 & 1 & $\mathbf{2}$ \\
\hline TOPLAM & $\mathbf{4}$ & $\mathbf{1 3}$ & \\
\hline
\end{tabular}

Çalışmada beşinci olarak YİKOB yöneticilerine bir yerel yönetim organı olan il özel idaresinin kaldırılması ve bazı görev ve sorumluluklarının merkezi bir teşkilat olan YİKOB'a devredilmesinin yerel demokrasiye zarar verip vermediği sorusu yöneltilmiştir. Tablo 5 'te görüldüğü üzere görüşülen yöneticilerin sadece 5'i il özel idaresinin kaldırılmasının yerel demokrasiyi olumsuz etkilediğini düşünmektedir. 11 yönetici ise ilde hala bir meclisin var olmasından dolayı olumsuz görmemektedir.

Tablo 5. IÖİ Kaldırılmasının Yerel Demokrasiye Etkisi Hakkındaki Görüşler

\begin{tabular}{|c|c|c|c|}
\hline Görüșülen İller & Olumlu & Olumsuz & Çekimser \\
\hline Aydın & 3 & 1 & - \\
\hline Denizli & 3 & - & 1 \\
\hline İzmir & 1 & 3 & \\
\hline Manisa & 2 & 1 & 2 \\
\hline Muğla & 2 & - & $\mathbf{3}$ \\
\hline TOPLAM & $\mathbf{1 1}$ & $\mathbf{5}$ & \\
\hline
\end{tabular}

Çalışmada altıncı olarak il özel idaresinden YİKOB'a devredilen görev ve sorumlulukların yerine getirilmesi hususunda YİKOB'un başarılı olup olmadığ 1 hakkındaki görüşleri sorulmuştur. Tablo 6'da görüldüğü üzere görüşülen yöneticilerden sadece 4 yönetici YİKOB'un başarılı olduğunu düşünmektedir. Bunun nedeni büyükşehir belediyelerinin pek çok sorumluluğu yerine getiriyor olmasıdır. Bazı yöneticiler ise bakanlıkların ildeki yatırımlarını yapacak kurumun kalmaması ve YİKOB’un bu görevi üstlenmesi nedeniyle olumlu görmektedir.

Tablo 6.YİKOB'un Başarılı Olup Olmadığı Hakkındaki Görüşler

\begin{tabular}{|c|c|c|c|}
\hline Görüșülen İller & Evet & Hayır & Çekimser \\
\hline Aydın & 1 & 1 & 2 \\
\hline Denizli & - & 4 & - \\
\hline İzmir & 1 & 3 & 1 \\
\hline Manisa & 1 & 1 & 1 \\
\hline Muğla & 1 & 2 & $\mathbf{4}$ \\
\hline TOPLAM & $\mathbf{4}$ & $\mathbf{1 1}$ & \\
\hline
\end{tabular}

Çalışmada yedinci olarak YİKOB'un kurulmasının yerellik ilkesine zarar verip vermediği sorusu yöneltilmiştir. Tablo 7'de görüldüğü üzere görüşülen yöneticilerin sadece 5'i YİKOB'un kurulmasının yerellik ilkesini olumsuz etkilediğini düşünmektedir. Bu konuda 3 yönetici çekimser kalırken, 11 yönetici zarar vermediğini düşünmektedir. Bu düşüncenin temelinde, yerel yönetim birimi olan il özel idaresi kapatıldıktan sonra görev ve sorumluluklarının büyükşehir belediyesine aktarılması ve büyükşehir belediyelerinde hala bir meclisin varlığını koruması bulunmaktadır.

Tablo 7. YİKOB Kurulmasının Yerellik İlkesine Etkisi Hakkındaki Görüşler

\begin{tabular}{|c|c|c|c|}
\hline Görüşülen İller & Olumlu & Olumsuz & Çekimser \\
\hline Aydın & 2 & 1 & 1 \\
\hline Denizli & 3 & 1 & \\
\hline İzmir & 2 & 2 & \\
\hline Manisa & 2 & 1 & 2 \\
\hline Muğla & 2 & - & $\mathbf{3}$ \\
\hline TOPLAM & $\mathbf{1 1}$ & $\mathbf{5}$ & \\
\hline
\end{tabular}


Çalışmada sekizinci olarak,YİKOB'ların kuruluş kanununda tüzel kişiliğe haiz olmayıp daha sonra yapılan düzenlemeyle tüzel kişilik kazandırılmış olmasının sebeplerinin ne olduğu sorusu yöneltilmiştir. Tüzel kişiliğin kazandırılması ile ilgili öne çıkan üç görüş Tablo 8'de gösterilmiştir.

Tablo 8.YİKOB'a Tüzel Kişilik Kazandırılması Hakkındaki Genel Görüşler

\begin{tabular}{|l|c|c|c|}
\hline \multicolumn{1}{|c|}{ Görüşler } & Evet & Hayır & Çekimser \\
\hline Bürokrasinin azaltılması & 14 & - & 5 \\
\hline Başkanlığa işlevsellik kazandırılması & 19 & - & - \\
\hline Yerel yatırımların yapılabilmesi & 14 & - & 5 \\
\hline
\end{tabular}

YİKOB’lara tüzel kişilik kazandırılmasının diğer sebepleri ise şu şekilde ifade edilmiştir:

- YİKOB'ların daha işlevsel hale getirilmesi,

- Hizlı karar alınabilmesine zemin hazırlanılması ve zaman kaybının engellenmesi,

- YİKOB'a ait bir bütçenin olabilmesi,

- Daha güçlü bir yapıya kavuşturulması,

- Harcama yetkisinin olabilmesi,

- $\quad$ Gelir getirici faaliyetlerde bulunabilmesi.

Çalışmada dokuzuncu olarak YİKOB'un organizasyon şemasında yer alan rehberlik ve denetim müdürlüğü biriminin faaliyetleri ve özellikle YİKOB'ların kuruluş kanununda yer alan ildeki yatırım ve hizmetlerin etkinliği noktasındaki denetim yetkisi kapsamında denetim yapılıp yapılmadığ sorusu yöneltilmiştir. Tablo 9'da görüldügü üzere görüşülen yöneticilerin sadece 2'si YİKOB'un ildeki yatırımları denetlediği yönünde fikir belirtmişlerdir. Geriye kalan 16 yönetici bu konuda YİKOB’un bir denetim yapmadığını ve ilgili müdürlüğün aktif olmadığını ifade etmişlerdir.

Tablo 9.YİKOB' ların İldeki Yatırımları Denetleme Görevi Hakkındaki Görüşler

\begin{tabular}{|c|c|c|c|}
\hline Görüşülen İller & Evet & Hayır & Çekimser \\
\hline Aydın & 1 & 3 & - \\
\hline Denizli & - & 4 & 1 \\
\hline İzmir & 1 & 2 & - \\
\hline Manisa & - & 3 & $\mathbf{1}$ \\
\hline Muğla & - & 4 & $\mathbf{1 6}$ \\
\hline TOPLAM & $\mathbf{2}$ &
\end{tabular}

İlgili müdürlüğün aktif olmadığını düşünen yöneticiler gerekçelerini şu şekilde açıklamıştır:

- Denetimin nasıl ve neye göre yapılacağına dair bir bilginin bulunmaması,

- YİKOB'un ilgili müdürlüğüne benzer bir müdürlüğün doğrudan valiliğe bağlı bir müdürlükçe yerine getiriliyor olması ve o müdürlüğün çok daha etkin olması,

- YİKOB adına denetim yapacak ilgili müdürlüğe bağlı personelin bulunmaması.

İldeki yatırımların etkin ve verimliliğinin denetlenmesi yetkisine haiz olan YİKOB'ların denetlenmesi konusunda kuruluş kanununda özellikle belirtilen bir husus bulunmamaktadır. $\mathrm{Bu}$ kapsamda çalışmada onuncu olarak YİKOB'ların kaç defa denetlendiği sorusu yöneltilmiştir. Tablo 10'da görüldügü üzere, Muğla YİKOB 2 ve İzmir YİKOB 1 defa Sayıştay denetimine tabi tutulmuştur. Diğer 3 YİKOB ise henüz denetlenmemiştir. 
Tablo 10.YIKOB'ların Denetimi İle İlgili Bilgiler

\begin{tabular}{|c|c|c|}
\hline Görüșülen İller & Denetlendi & Denetlenmedi \\
\hline Aydın YİKOB & & $X$ \\
\hline Denizli YİKOB & & $X$ \\
\hline İzmir YİKOB & $1 \mathrm{kez}$ & $\mathrm{X}$ \\
\hline Manisa YİKOB & & \\
\hline Muğla YİKOB & $2 \mathrm{kez}$ & \\
\hline
\end{tabular}

Çalışmada on birinci olarak YİKOB'ların kuruluş kanununda yer alan ve sonradan yapılan düzenleme ile kaldırılan idari ve teknik müdürlük ayrımı hakkındaki görüşleri sorulmuştur. Yöneticilerin görüşlerine göre iki husus ön plana çıkmıştır. Tablo 11'degörüldüğü üzere görüşülen yöneticiler idari ve teknik müdürlük ayrımının varlığı ile kaldırılması arasında herhangi bir değişiklik olmadığı konusunda hemfikirdirler.

Tablo 11.YİKOB'daki İdari ve Teknik Müdürlük Hakkındaki Genel Görüşler

\begin{tabular}{|l|c|c|c|}
\hline \multicolumn{1}{|c|}{ Görüsşler } & Evet & Hayır & Çekimser \\
\hline Teknik ve idari müdürlük ayrımı hatalıydı. & 14 & - & 5 \\
\hline $\begin{array}{l}\text { Teknik ve idari müdürlük ayrımının kaldırılması } \\
\text { ile değişen bir şey olmadı. }\end{array}$ & 19 & - & - \\
\hline
\end{tabular}

Çalışmada on ikinci olarak yöneticilere ildeki yatırımların etkin ve verimliliğini denetleme yetkisinin valiliğe bağlı bir merkez teşkilatı olan YİKOB'lara verilmesinin valilik ile büyükşehir belediye başkanlığı arasında bir güç çatışması doğurup doğurmadığı sorusu yöneltilmiştir. Tablo 12'de görüldüğü üzere Aydın, İzmir, Manisa ve Muğla'da ildeki yatırımların etkin ve verimliliğini denetleme yetkisinin güç çatışmasına sebep olduğu ortaya çıkmıştır. Yine aynı illerde İÖİ mallarının paylaşımı konusunda da sorunlar yaşandığ 1 belirtilmiştir.

Tablo 12. Güç Çatışması Hakkındaki Genel Görüşler

\begin{tabular}{|l|c|c|c|}
\hline \multicolumn{1}{|c|}{ Görüşler } & Evet & Hayır & Çekimser \\
\hline Güç Çatışması Yaşandı. & $\begin{array}{c}\text { Aydın, İzmir, } \\
\text { Manisa, Muğla. }\end{array}$ & Denizli & - \\
\hline ÏÖİ Mallarının Paylaşımında Sorun Yaşandı. & $\begin{array}{c}\text { Aydın, İzmir, } \\
\text { Manisa, Muğla. }\end{array}$ & Denizli & - \\
\hline
\end{tabular}

Görüşmeler neticesinde büyükşehir belediyesi siyasi iktidardan farklı olan tüm illerde (Aydın, İzmir, Manisa ve Muğla) il özel idaresinden kalan malların devir, tasfiye ve paylaşımında ciddi sorunlar yaşandığı tespit edilmiştir. Devir, tasfiye ve paylaşım komisyonunun vermiş olduğu kararların neredeyse tamamına bir taraf (büyükş̧ehir belediyesi ya da valilik) itiraz etmiş ve itiraz edilen taşınır taşınmaz mallar davalık durumdadır. Ayrıca, hem büyükşehir belediyesinin hem de YIKKOB'un ilde yatırım yapma yetkisinin olmasının ve KIRDES projesiyle YİKOB'un yatırım yapma yetkisinin aktif hale gelmesinin güç çatışmaları yaşanmasına sebep olduğu belirtilmiştir.

Ayrıca büyükşehir belediyesi siyasi iktidardan farklı olan tüm illerde YİKOB binaları oldukça kötü durumdadır. Özellikle Manisa'daki YİKOB binası eski il özel idaresi lojmanları olması nedeniyle oldukça küçük ve kullanışsızdır. İzmir YİKOB hizmet binasının yarısını Konak Belediyesi'nin kazanmasıyla, yarısı kendisine ait olan bir binada hizmet ve faaliyetlerini sürdürmeye devam etmektedir. Muğla YİKOB ise, belediyenin bir yer göstermemesinden dolayı hizmet binası kiraladıklarını ifade etmişlerdir. Ayrıca yine büyükşehirlerde merkezi hükümetten farklı partilerin yönetimde olmasının bazı sorunlar oluşturduğu dile getirilmiştir. Bu sorunları şu şekilde sıralamak mümkündür:

- Kapatılan il özel idaresi personelinin siyasi görüşü ne olursa olsun il özel idaresi personeli olduğu için mevcut siyasi iktidar tarafı olarak görüldüğü ve niteliklerine bakılmaksızın en pasif makamlarda görevlendirildiği, 
- Büyükşshir belediyesinin muhalif ilçe belediyelerine veya mahallelere hizmet götürmediği,

- Büyükşehir belediyelerinin hizmet götürmediği ilçe belediyeleri için YİKOB aracıllğıyla merkezi idarenin hizmet götürmesinin yetki çatışmasına sebep olduğu, belirtilmiştir.

Çalışmada on üçüncü olarak İçişleri Bakanlığı'nın YİKOB'un görüşlerini alıp almadığı sorulmuştur. Tablo 13'te görüldüğü üzere, yöneticilerin sadece 6's1 YİKOB'un önerilerinin Bakanlık tarafından dikkate alındığını ancak sadece tüzel kişiliğin verilmesiyle ilgili önerinin gerçekleştiğini ifade etmişlerdir.

Tablo 13. İçişleri Bakanlığı ile YİKOB Arasındaki İlişki Hakkında Görüşler

\begin{tabular}{|c|c|c|c|}
\hline Görüşülen İller & Evet & Hayır & Çekimser \\
\hline Aydın & - & 2 & 2 \\
\hline Denizli & 1 & 2 & 1 \\
\hline İzmir & 1 & 2 & 1 \\
\hline Manisa & 2 & 1 & 1 \\
\hline Muğla & 2 & 1 & $\mathbf{5}$ \\
\hline TOPLAM & $\mathbf{6}$ & $\mathbf{8}$ & \\
\hline
\end{tabular}

Çalışmada on dördüncü olarak yöneticilere valilerin seçimle gelmesi konusundaki görüşleri sorulmuştur. Tablo 14'te görüldüğü üzere görüşülen yöneticilerin sadece 4'ü valilerin seçimle gelmesi konusunda olumlu fikir belirtmişlerdir. Hayır diyen yöneticilerin ortak görüşü Türkiye için bu sistemin erken olduğu yönündedir.

Tablo 14. Valilerin Seçimle Gelmesi Hakkındaki Görüşler

\begin{tabular}{|c|c|c|c|}
\hline Görüşülen İller & Evet & Hayır & Çekimser \\
\hline Aydın & - & 2 & - \\
\hline Denizli & 1 & 3 & \\
\hline İzmir & 1 & 3 & 1 \\
\hline Manisa & 1 & 2 & $\mathbf{3}$ \\
\hline Muğla & 1 & 2 & $\mathbf{1 2}$ \\
\hline TOPLAM & $\mathbf{4}$ & & \\
\hline
\end{tabular}

Görüşülen 19 yöneticinin sorulara verdiği cevaplar Tablo 15'te genel hatlarıyla özetlenmiştir. Görüşülen yöneticilerin 11'i YIKOOB'ların kurulmasına olumlu bakmamakta ve 13'ü büyükșehir olmayan 51 il içinde YİKOB kurulması fikrini desteklememektedir. Yöneticilerin olumlu yönde çoğunluk olarak birleştiği konu ise, YİKOB'un kurulmasıyla yerel demokrasiye ya da yerellik ilkesine bir zarar gelmediği konusudur. Bu düşüncelerinin gerekçesi ise büyükşehir belediyelerinde aktif olarak faaliyetlerini yürüten bir meclisin var olmasıdır.

Tablo 15.Çalışma Bulgularının Genel Olarak Değerlendirilmesi

\begin{tabular}{|l|c|c|c|}
\hline \multicolumn{1}{|c|}{ Sorular } & Olumlu & Olumsuz & Çekimser \\
\hline YİKOB'ların Kurulması Hakkındaki Görüşler & 6 & 11 & 2 \\
\hline $\begin{array}{l}\text { Tüm İllerde YİKOB'ların Kurulması Hakkındaki } \\
\text { Görüşler }\end{array}$ & 4 & 13 & 2 \\
\hline $\begin{array}{l}\text { YİKOB'ların kurulmasının Yerel Demokrasiye Etkisi } \\
\text { Hakkındaki Görüşler }\end{array}$ & 11 & 5 & 3 \\
\hline $\begin{array}{l}\text { YİKOB'larınİÖİnin Boşluğunu Doldurması } \\
\text { Hakkındaki Görüşler }\end{array}$ & 4 & 11 & 4 \\
\hline $\begin{array}{l}\text { YİKOB'ların Kurulmasının Yerellik İlkesine Etkisi } \\
\text { Hakkındaki Görüşler }\end{array}$ & 11 & 5 & 3 \\
\hline $\begin{array}{l}\text { İçşleri Bakanlığı ile YİKOB Arasındaki İlişki } \\
\text { Hakkındaki Görüşler }\end{array}$ & 6 & 8 & 5 \\
\hline Valilerin Seçimle Gelmesi Hakkındaki Görüşler & 4 & 12 & 3 \\
\hline
\end{tabular}


Çalışma bulguları genel olarak değerlendirildiğinde, YİKOB'un kurulmasına olumlu bakan yöneticiler ile tüm illerde YİKOB kurulmasını destekleyen yöneticiler arasında sayısal yakınlık bulunmaktadır. YİKOB'un kurulması yerel demokrasiyi olumsuz etkilemedi diyen yöneticiler ile yerellik ilkesine olumsuz etkisi olmadığını düşünen yönetici sayıları aynıdır. YİKOB'un kurulmasına olumsuz bakan yöneticilerle YİKOB'un il özel idaresinin boşluğunu dolduramıyor diyen yönetici sayısı da benzerlik göstermektedir.

\section{Sonuc}

Türkiye'de son yıllarda yerel yönetimler ile ilgili kararlar hızlı bir şekilde alınmış ve uygulamaya konulmuştur. 1864 Vilayetler Nizamnamesi ile kurulan il özel idaresi ile ilgili olarak 1987 yılına kadar neredeyse hiçbir değişiklik yapılmazken, 2005 yılında 5302 sayılı Kanun ve 2012 yılında 6360 sayılı Kanun ile çok önemli değişiklikler yapılmıştır. 2005 yılında önemli değişiklikler yapılmasına rağmen 2012 yılında köklü bir değişikliğe gidilmesi ise dikkat çekmektedir.

İl özel idaresi ile ilgili olarak yapılan en köklü değişiklik büyükşehir olan illerde il özel idarelerinin kapatılarak YİKOB'ların kurulmasıdır. Yerelde yeni bir merkezi yönetim birimi kurulması, beraberinde merkezileşme tartışmalarını getirmiştir. Ayrıca, il özel idareleri ile ilgili olarak çok kısa bir süre içinde köklü bir değişiklik yapılma ihtiyacı duyulması kanunların plansız olarak yapıldığı eleştirilerine neden olmuştur. Son olarak ise, YİKOB'lara kurulduktan sonra tüzel kişilik kazandırılması eleştirileri artırmıştır.

KHK'larla yatırım yetkisi verilen YİKOB'ların yatırım için bütçesinin olmaması merkezileşme eleştirilerini tam olarak haklı çıkarmamaktadır. Ancak yatırım için bütçesi de olduğunda merkezileşme eleştirilerini haklı çıkarabilir. Çünkü ildeki ya da kırsal kesimdeki yatırımlara öncesinde çoğunlukla yerel yöneticiler karar verirken, artık merkezi idare kuruluşu olan YİKOB karar verir konuma gelecektir.

Çalışmada YIKKOB'un işleyişi ile ilgili olarak teşkilat yapısı, görev, yetki ve sorumlulukları, mali yapısı, denetimi ve merak edilen bazı konular ile ilgili sorular sorulmuştur. $\mathrm{Bu}$ sorular çerçevesinde yöneticilerin YİKOB'un daha işlevsel hale gelebilmesi için sundukları öneriler; siyasal bir karar organı olmayan ancak vergilerden pay alabilen, kendi gelirlerini oluşturabilen, oluşturulan bu gelirler doğrultusunda yatırımlar yapabilen, personel istihdam edebilen bir yapıyı tarif etmektedir. Tarif edilen bu yapı il genel meclisinin olmadığı bir il özel idaresini anımsatmaktadır.

Görüşmeler neticesinde Ege Bölgesi'ndeki YİKOB'ların en büyük sıkıntıyı iş/personel sayısı konusunda yaşadığı tespit edilmiştir. Görüşmelerde ön plana çıkan bir durum da, büyükşehir belediye yönetimleri ile merkezi hükümetin farklı siyasi partiye mensup olması durumunda sikıntılar yaşanmasıdır. İl özel idaresinden kalan malların paylaşımı ve yetki ve sorumluluklar bağlamındaki fikir ayrılıkları bu sorunların temelini oluşturmaktadır. Büyükşehir belediyeleri ilde yatırım yetkisinin sadece kendilerinde olduğunu savunurken, merkezi hükümet aynı ilde YİKOB vasıtasıyla bazı yatırım ve hizmetler yapmak isteyebilmektedir. Bu durum bazı illerde güç çatışmasına dönüşebilmektedir. $\mathrm{Bu}$ çerçevede YİKOB'lar ile ilgili üç temel sorun ortaya çıktığı tespit edilmiştir. Bunlar:

- Görev tanımının tam olarak belli olmamasından dolayı yetki karmaşası ve buna bağlı olarak işleyişlerinde durağanlık söz konusu olabilmesi.

- Gelir kalemlerinin oluşturulmaması nedeniyle yatırım yetkisini kullanamaması ve buna bağlı olarak etkin olarak görevini yerine getirememesi.

- Personel yetersizliğinden dolayı personelin fazla çalışması.

Yöneticilerle yapılan görüşmelerde, il özel idaresi kaldırılmayan 51 il için de YİKOB'ların kurulması konusunun İçişleri Bakanlığı tarafından YİKOB yöneticilerine sorulan bir soru olduğu 
belirtilmiştir. Özellikle 2019 yerel seçimlerinden önce böyle bir değişiklik yöneticilerce beklenmiş, ancak gerçekleşmemiştir.

Çalışma neticesinde görüşülen 5 ildeki YİKOB'ların birbirlerinden bazı konularda farkl1laştıkları da gözlemlenmiştir. Bu farkl11ıklar şu şekilde özetlenebilir:

- Bazı YİKOB'larda harcama yetkilisi vali iken, bazı YİKOB'larda birim müdürleridir.

- Bazı YİKOB'lar ildeki diğer kurum personellerinden ihtiyaç duyulması halinde görevlendirme ile personel ihtiyacını karşılarken, bazıları yetkisi olmasına rağmen gerçekleştirememiştir.

- Bazı YİKOB'lar kurulduğundan beri hiç denetlenmemişken, bazıları iki denetim geçirmiştir.

- Bazı YİKOB'lar büyükşehir belediyesinin yatırım ve hizmetlerini denetleme yetkilerinin olmadıklarını düşünürken, bazıları bu yetkiye haiz olduklarına inanmaktadır.

Görüşülen yöneticilerin de fikirleri doğrultusunda YİKOB'lar ile ilgili olarak şu konularda değişiklik yapılabilir: olmamalıdır.

- YİKOB'a personel istihdam etme yetkisi verilmelidir. Ama bu yetki nepotizme sebep

- Genel olarak kurumun tanımı, görevleri, yetkilerinin gözden geçirilmesi ve netleştirilmesi gerekmektedir.

- YİKOB'larda mühendis kökenli bir vali yardımcısı olmalıdır.

- Geçici görevlendirmelere son verilmelidir.

- Fiziki ortam yetersizliği olan illerde, bu eksiklik giderilmelidir.

- YIKKOB'lar ilde yatırım yapabilme yetkilerini kullanacak ise gelir kalemlerinin netleştirilmesi olumlu katkı sağlayacaktır. Ayrıca bu yatırımlar ilin ihtiyacı doğrultusunda belirlenmeli, vali siyasi baskılara maruz bırakılmamalıdır.

Yapılan çalışma neticesinde kapatılan il özel idaresinin bazı görev ve sorumluluklarını üstlenecek bir kurum olmadığından dolayı YİKOB'ların ortaya çıkmasının elzem bir durum haline geldiği anlaşılmaktadır. Sonuç olarak, 6360 sayılı Kanun ile kurulan YİKOB’lar ile ilgili kendi çalışanları tarafından dahi bir memnuniyetsizlik durumu bulunmaktadır. Bu nedenle görev tanımı, yetki ve sorumlulukları, teşkilat ve personel yapısı ve gelir ve giderleri yeniden ele alınarak belirtilen hususlardaki eksiklikler giderilmelidir.

\section{KAYNAKÇA}

28962 Sayılı Yönetmelik

Akman, Ç., Kalender, M . (2018). Yerelde Yeni Bir Merkezi Yönetim Birimi: Yatırım İzleme ve Koordinasyon Başkanlığı. Ankara Üniversitesi SBF Dergisi, 73 (4), 1025-1056.

Altıntaş, Osman (2007), İl Özel İdaresi Harcamalarının Mevcut ve Potansiyel Olarak Fonksiyonel Analizi, DPT Uzmanlık Tezi, Ankara.

Aytaç, Fethi (1995), “İl Özel İdareleri Hakkında Düşünceler”, Yeni Türkiye Dergisi,1(4), ss. 377-389.

Cumhurbaşkanlığı Teşkilatı Hakkında Cumhurbaşkanlığı Kararnamesi (CBK-1), Cumhurbaşkanlığı Kararnamesinin Sayısı: 1, Yayımlandığı Resmî Gazetenin Tarihi - Sayısı: 10/7/2018 - 30474 
Cumhurbaşkanlığı Teşkilatı Hakkında Cumhurbaşkanlığı Kararnamesi (CBK-1), Cumhurbaşkanlığı Kararnamesinin Sayısı: 1, Yayımlandığı Resmî Gazetenin Tarihi - Sayısı: 10/7/2018 - 30474

Ertabak, Ülkü (1998), “İl Özel İdarelerini Yeniden Yapılanması” İlke Yayıncılık, İstanbul.

Eryılmaz, Bilal (2004), Kamu Yönetimi, Erkam Matbaası, İstanbul.

Giritli, İsmet, Bilgen, Pertev ve Akgüner, Tayfun (2001), İdare Hukuku,Der Yayınları, İstanbul.

Güzel, Mehmet Nuri (2010),̇ll Özel İdaresi, Dicle Üniversitesi Sosyal Bilimler Enstitüsü Kamu Hukuku Anabilim Dalı, Yüksek Lisans Tezi, Diyarbakır.

Hakyemez, Şevki (1998), “İl Özel İdarelerinin İşlevi, Organları ve Rolleri”,SayıştayDergisi, 3(31), ss. 169-183.

http://www.resmigazete.gov.tr/eskiler/2014/04/20140404-31.htm (Erişim Tarihi: 16.10.2018).

İçişleri Bakanlığı Teşkilat ve Görevleri Hakkında Kanun (1985),3152 sayılı İçişleri Bakanlığı Teşkilat ve Görevleri Hakkında Kanun, 23 Şubat 1985.

Karakılçık, Yusuf (2013), Yerel Yönetimler, Seçkin Yayıncılık, Ankara.

Kartal, Nazım (2013), “Tanzimat'tan Cumhuriyete Osmanlı'da Mülki İdare”, Akademik Yaklaşımlar Dergisi, 4 (1),ss. 1-24.

Keleş, Ruşen (2000), Yerinden Yönetim ve Siyaset (4. Bask1), Cem Yayınevi, İstanbul.

Nadaroğlu, Halil (2001), Mahalli İdareler, Beta Yayıncılık, İstanbul.

Ortaylı, İlber (1985), Tanzimat'tan Cumhuriyet'e Yerel Yönetim Geleneği, Hil Yayıncılık, İstanbul.

Parlak, Bekir (2015), Bir Yerel Yönetim Olarak Geçmişten Günümüze İL Özel İdareleri: Tarihçesi, Kuruluşu, Görev ve Yetkileri İle Bir Gelecek Perspektifi, İdari ve Mali Açıdan Türkiye'de Yerel Yönetimler, Ed: Mehmet Mecek vd., BEKAD Yayınları, No 22, Ankara.

Parlak, Bekir ve Mustafa Ökmen (2015), Yerel Yönetimler, Ekin Basım Yayın Dağıtım, 4. Baskı, Bursa.

Tekeli, İlhan (1983), "Yerel Yönetimlerde Demokrasi ve Türkiye'de Belediyelerin Gelişim”, Amme İdaresi Dergisi, 16 (2): 3-22.

Ulusoy, Ahmet ve Akdemir, Tekin (2001), Mahalli İdareler, Seçkin Yayınevi, Ankara. 